\title{
Application of a new in situ calibration technique for gamma spectrometry and comparison of in situ and laboratory measurements
}

\author{
Davor Rašeta, Branko Petrinec, Dinko Babić, and Marko Šoštarić \\ Institute for Medical Research and Occupational Health, Zagreb, Croatia
}

[Received in July 2020; Similarity Check in July 2020; Accepted in February 2021]

In situ gamma ray spectrometry was developed to quickly measure large areas of land following nuclear accidents. However, a proper calibration of detectors for in situ measurements is a long and complicated process. One tool designed to make this calibration quick is the InSiCal software. We compared 5,000 s in situ measurements with two different HPGe detectors calibrated using the InSiCal software and laboratory measurements of samples collected at the same locations. Our findings suggest that in situ gamma spectrometry using InSiCal software can provide reasonably accurate data, but some improvements are needed.

KEY WORDS: emergency; HPGe spectrometers; InSiCal software; radiation; radionuclide measurements

In situ gamma-ray spectrometry has become common since the late 1960s. In the beginning, it was used primarily as part of radionuclide measurements of nuclear weapon testing fallout and measurements of background radiation $(1,2)$. The first elaborate description of the method was published in 1972 (3). The first in situ measurements were performed using $\mathrm{NaI}(\mathrm{Tl})$ and $\mathrm{Ge}(\mathrm{Li})$ detectors. For more than three decades, portable HPGe gamma spectrometers have been available and preferred to scintillator detectors due to their superior resolution.

In the 1990s, updates on method descriptions became available $(4,5)$. The technique was also adopted by the International Atomic Energy Agency (IAEA) for characterisations of contaminated sites for remediation purposes (6) and for radioactivity monitoring following a nuclear or radiological emergency (7). In 2013, the International Organization for Standardization (ISO) issued a guide for in situ gamma spectrometric measurement in soil which became international reference for how to identify radionuclides and quantify their activity with the method (8).

Compared to traditional sampling and laboratory measurements in situ gamma spectrometry is quicker, cheaper, and less sensitive to local variations in samples. It can quickly cover a large area and identify radiation hot spots. However, it takes time and effort to raise it to the level of laboratory results. Problems with in situ measurements arise from calibration issues, as detectors are employed outside the laboratory environment, where the efficiency for different angles has to be calibrated and

Corresponding author: Branko Petrinec, Institute for Medical Research and Occupational Health, Ksaverska cesta 2, 10000 Zagreb, Croatia E-mail:petrinec@imi.hr where samples do not have easily measured and determined properties.

Recently, the Norwegian Radiation Protection Authority (NRPA) developed a tool that significantly simplifies the in situ calibration of the detector (9). Using this tool, which we acquired from the IAEA, we calibrated two field detectors with different efficiencies, made by different manufacturers, and performed gamma spectrometric in situ measurements at eight locations in Croatia. We also collected samples from those locations and performed gamma spectrometry in the laboratory after leaving the samples in sealed sampling dishes for three months to ensure the equilibrium of radionuclides in ${ }^{238} \mathrm{U}$ and ${ }^{232} \mathrm{Th}$ decay chains. The results from both detectors used in the field were largely in good agreement.

In all the measurements, the following radionuclides were analysed: ${ }^{40} \mathrm{~K}$ (using the peak at $1460.8 \mathrm{keV}$ ), ${ }^{238} \mathrm{U}$ (using the ${ }^{234} \mathrm{Th}$ peak at $63.3 \mathrm{keV}$ and the double peak at 92.4 and $92.8 \mathrm{keV}$ ), ${ }^{232} \mathrm{Th}$ (using ${ }^{228} \mathrm{Ac}$ peaks at $333.3 \mathrm{keV}$, $911.2 \mathrm{keV}$, and $969.0 \mathrm{keV}$ ), ${ }^{214} \mathrm{Bi}$ (using the peaks at $609.3 \mathrm{keV}$ and $1120.3 \mathrm{keV}$ ), ${ }^{214} \mathrm{~Pb}$ (using the peaks at $295.2 \mathrm{keV}$ and $351.9 \mathrm{keV}$ ) and ${ }^{137} \mathrm{Cs}$ (using the peak at $661.7 \mathrm{keV})$.

\section{EMERGENCY CONSIDERATIONS}

During the preparations for the in situ and laboratory measurements, we simulated emergency conditions. As the Croatian emergency preparedness and response (EPR) plan and all related plans and procedures are still under development and we could not rely on any such reference procedure, we based our decisions on our knowledge of the 
topic and discussions with the regulator as part of the development of the Croatian EPR plan.

The two key considerations were time management and the ability to fit work into standard working hours. While the second consideration seems curious, even wrong, it is based on the discussions with the regulator. The regulator is aware of the danger of burning out people, experts in a relevant field in particular, during response to an emergency, as Croatia has a precious few, so the intention was to start with response as soon as possible and not allow people to work longer than eight hours a day.

\section{METHOD}

\section{Mathematical model of calibration}

The efficiency $\left(\varepsilon_{E}\right)$ of a detector at a given energy can be calculated from the measurement of the net rate of detected photons from a known source at that energy $\left(R_{C E}\right)$, activity of the source $\left(A_{C}\right)$, and emissivity of the source at that energy $\left(p_{E}\right)$ :

$\varepsilon_{E}=\frac{R_{C E}}{p_{E} \cdot A_{C}}$

This efficiency can be expressed as a product of three separate factors: the intrinsic detector efficiency $\left(\eta_{0}\right)$, correction factor for different responses depending on the angle of the gamma ray $(W)$, and the correction factor for the geometry of the sample $(G)(9)$ :

$$
\varepsilon_{E}=\eta_{0} \cdot W \cdot G \text {, }
$$

In laboratory conditions, the geometry of a measured sample can be controlled and $\varepsilon_{E}$ can be calculated for a range of energies by using a known source in the same geometry. In the field, however, uncollimated detectors cannot make use of a reference source in the same geometry as a measured sample.

Correction factors have been amply analysed before $(1-5,8,9)$ and we will not repeat the analysis here.

From the equations [1] and [2], standard uncertainty for the activity of the source can be expressed as:

$$
\frac{u\left(A_{C}\right)}{A_{C}}=\sqrt{\left(\frac{u\left(R_{C E}\right)}{R_{C E}}\right)^{2}+\left(\frac{u\left(p_{E}\right)}{p_{E}}\right)^{2}+\left(\frac{u\left(\varepsilon_{E}\right)}{\varepsilon_{E}}\right)^{2}},
$$

and for the detector efficiency factor as:

$\frac{u\left(\varepsilon_{E}\right)}{\varepsilon_{E}}=\sqrt{\left(\frac{u\left(\eta_{0}\right)}{\eta_{0}}\right)^{2}+\left(\frac{u(W)}{W}\right)^{2}+\left(\frac{u(G)}{G}\right)^{2}}$

Nir-El and Haquin (10) have given a very good discussion about differences in uncertainty calculation between laboratory and in situ measurements.

\section{InSiCal}

Now, relying on the guidelines issued by ISO and the Joint Committee for Guides in Metrology $(8,11)$, InSiCal automatically calculates these uncertainties. InSiCal is a software tool developed by NRPA to simplify in situ measurements. It can make use of a calibration made by the user $(3,12)$ but also has the ability to calculate the angular part of the calibration based on selected source distribution. It only requires the user to input peak response data (including uncertainty) for multiple energies and geometrical data about the crystal and to define the distribution of a selected radionuclide in soil. To calculate the angular correction factor InSiCal uses the Monte Carlo method.

InSiCal has four predefined distributions (9): surface distribution, uniform distribution, exponential distribution, and slab (or step) distribution. Surface distribution assumes that all radionuclides are in an infinitesimally thick layer at the surface. This distribution is appropriate for the measurements immediately after the release of radioactive material. Uniform distribution assumes that radionuclides are uniformly distributed in soil across an infinite depth. This assumption is usually appropriate for the measurements of naturally occurring radionuclides, unless core samples say otherwise. Exponential distribution assumes that the concentration of radionuclides in soil drops exponentially with depth. Slab distribution, in turn, assumes that radionuclide concentration in soil is uniform down to the depth where it drops to zero. Both of these assumptions are correct for radionuclides that had been leeching into soil from contaminated surface for a longer time.

In this study we used the InSiCal version 0.91 obtained through the IAEA.

\section{Calibration of detectors for in situ measurement}

In preparation for the measurements we discussed two possible calibration methods. One was the standard calibration method that involves measuring the peak response of a known ${ }^{152} \mathrm{Eu}$ source positioned $1 \mathrm{~m}$ from and directly below the detector and measuring angular responses

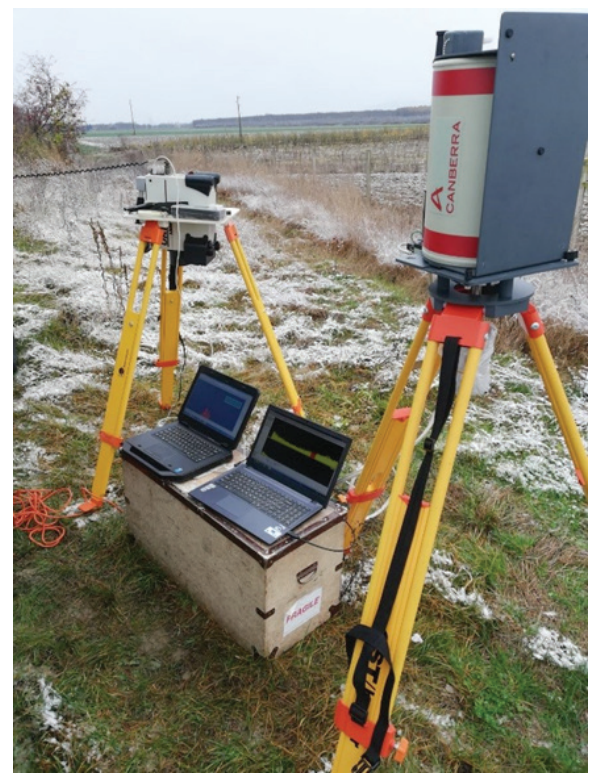

Figure 1 In situ measurement setup 
at every $10^{\circ}$ between $0^{\circ}$ and $90^{\circ}$ along the arc $1 \mathrm{~m}$ from the detector following the method described elsewhere $(1$, 7). The alternative method involves only peak response measurement and the use of InSiCal to calculate angular responses using the Monte Carlo method. As we simulated emergency conditions, we opted for the second method rather than wasting time moving the source every $10^{\circ}$ at exactly $1 \mathrm{~m}$ distance from the detector.

Two p-type HPGe detectors, one Canberra (Mirion Technologies Inc., San Ramon, CA, USA) with $54 \%$ relative efficiency at $1,332 \mathrm{keV}$ (hereinafter referred to as Detector A), cooled with liquid nitrogen, and the other Ortec Detective-Ex (Advanced Measurement Technology Inc., Oak Ridge, TN, USA) with $17 \%$ relative efficiency at $1,332 \mathrm{keV}$ (hereinafter referred to as Detector B), cooled electrically, were calibrated using a ${ }^{152} \mathrm{Eu}$ source positioned $1 \mathrm{~m}$ directly below the detector in the direction of its symmetry axis. The measurement lasted 17,000 s. For calibration we used gamma rays at energies of $121.78 \mathrm{keV}$, $244.70 \mathrm{keV}, 344.28 \mathrm{keV}, 778.90 \mathrm{keV}, 1112.08 \mathrm{keV}$, and $1,408.01 \mathrm{keV}$. The obtained measurements and detectors' geometry were input in the InSiCal program, which then calculated angular responses and created calibration files for the detectors.

\section{Site selection}

While Croatia does not have nuclear power plants, NPP Krško in Slovenia is located mere $10 \mathrm{~km}$ from the Croatian border, and NPP Paks in Hungary is but $65 \mathrm{~km}$ from the border. We therefore chose measurement sites in seven Croatian settlements closest to either of the NPPs. The idea was to characterise the sites most likely to be hit by radiation first and to prove that in situ characterisation can be done quickly, which is especially important in an emergency, and still be nearly as accurate as laboratory measurements.

\section{Measurements}

At each site we selected an area with uncultivated land and low vegetation (forest clearing or a meadow). Both detectors were placed $1 \mathrm{~m}$ above ground and each measurement lasted 5,000 s. This duration was based on the above-mentioned discussions with the regulator about the expected duration for in situ measurements in a real emergency (3000 to $5000 \mathrm{~s}$, less for presumed high levels of contamination).

The results of the measurements were input in InSiCal with calculated calibration, soil density (measured in the soil samples taken), and assumed distribution of radionuclides in soil. For in situ calculations we assumed uniform vertical distribution of ${ }^{238} \mathrm{U}\left({ }^{234} \mathrm{Th}\right),{ }^{232} \mathrm{Th}\left({ }^{228} \mathrm{Ac}\right)$, ${ }^{214} \mathrm{Bi},{ }^{214} \mathrm{~Pb}$, and ${ }^{40} \mathrm{~K}$ - the same as for all other naturally occurring radionuclides. However, considering that changes in land use may have resulted in accumulated ${ }^{40} \mathrm{~K}$ from plant remains in the upper layer of soil, we assumed slab (step) distribution for ${ }^{137} \mathrm{Cs}$ and for additional (control) calculation of ${ }^{40} \mathrm{~K}$.

At each measurement site we took soil samples down to a depth of $10 \mathrm{~cm}$. We removed the top layer of foliage and thoroughly mixed and dried each sample. Then we removed any pebbles and crushed, ground, and sieved the soil to obtain a uniform powder and put it into $200 \mathrm{~mL}$ plastic containers (approximately $3.5 \mathrm{~cm}$ deep and $8.6 \mathrm{~cm}$ in diameter). The containers were closed, sealed with tape, and sealed again in a plastic bag.

Since we simulated emergency measurements, no additional samples were taken to further characterise the soil and determine experimentally vertical distributions of radionuclides, including the relaxation coefficients for the exponential distribution of ${ }^{137} \mathrm{Cs}$. Without these data, we assumed the step distribution of ${ }^{137} \mathrm{Cs}$.

Laboratory measurements were taken three months later, after the decay chain restored its equilibrium. Not counting the time needed to reach the equilibrium, sample preparation and laboratory measurements took almost three weeks, which is too long for an emergency. For all laboratory measurements we used a single p-type HPGe detector (Canberra, $54 \%$ relative efficiency at 1,332 keV). The samples were put on top of the detector cap, and the geometry was standard for that detector, the same in which it was calibrated using certified multi-radionuclide calibration source. Each measurement lasted 80,000 s.

\section{RESULTS}

Table 1 lists the measurements sites, their geographic locations, and altitudes. Figures 2-6 compare laboratory and in situ measurement with both detectors. All the results are shown in $\mathrm{Bq} / \mathrm{kg}$. The $95 \%(2 \sigma)$ confidence intervals are shown around all the results. If no confidence interval is visible for some data point, it means that the interval in question is smaller than the size of the symbol marking the data point.

During the in situ measurements of ${ }^{238} \mathrm{U}$ at some locations, peaks at $63.3 \mathrm{keV}$ were impossible to determine, and we used only the double peak at 92.4 and $92.8 \mathrm{keV}$. At one location, it was impossible to determine any of the ${ }^{234} \mathrm{Th}$ peaks with Detector B. On average, Detector A yielded $34 \%$ and Detector B $55 \%$ higher ${ }^{238} \mathrm{U}$ concentrations than

Table 1 Measurement sites

\begin{tabular}{lccc}
\hline Site & Altitude & Longitude $\left({ }^{\circ} \mathbf{N}\right)$ & Latitude $\left({ }^{\circ} \mathbf{E}\right)$ \\
\hline Bregana & $187 \mathrm{~m}$ & 45.825 & 15.635 \\
\hline Klanjec & $169 \mathrm{~m}$ & 46.046 & 15.731 \\
\hline Plavić & $202 \mathrm{~m}$ & 46.116 & 15.613 \\
\hline Batina & $80 \mathrm{~m}$ & 45.840 & 18.848 \\
\hline Beli Manastir & $102 \mathrm{~m}$ & 45.753 & 18.637 \\
\hline $\begin{array}{l}\text { Baranjsko } \\
\text { Petrovo Selo }\end{array}$ & $89 \mathrm{~m}$ & 45.763 & 18.463 \\
\hline Zlatna Greda & $79 \mathrm{~m}$ & 45.721 & 18.867 \\
\hline
\end{tabular}




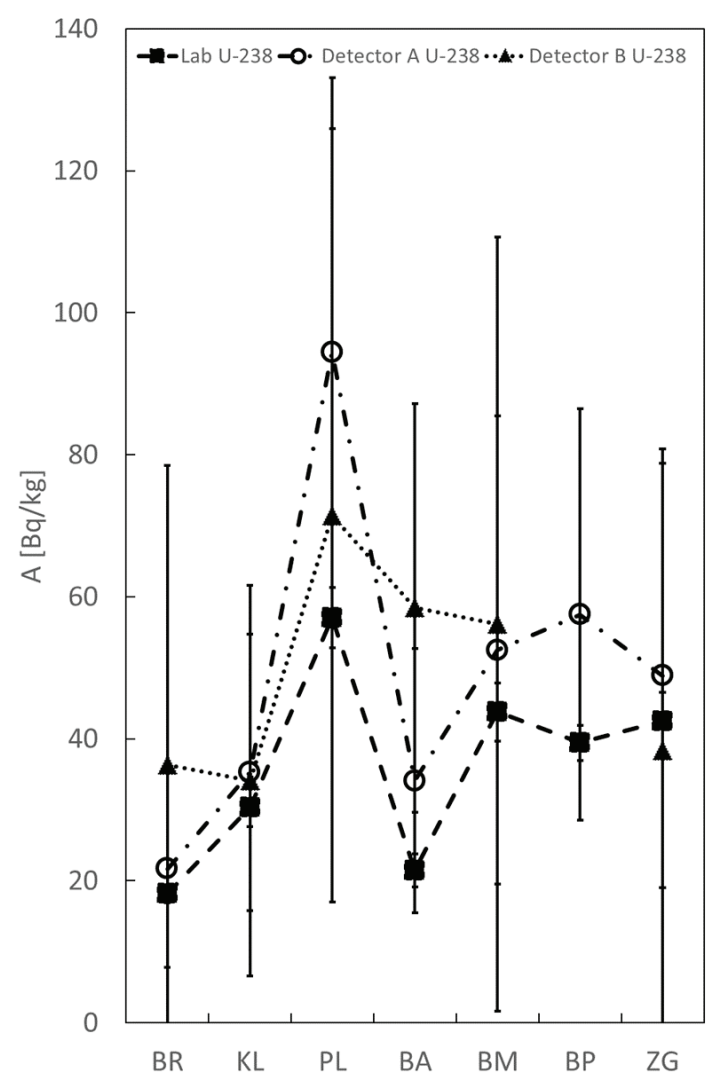

Figure 2 Results of ${ }^{238} \mathrm{U}$ measurements. BA - Batina; BM - Beli Manastir; BP - Baranjsko Petrovo Selo; BR - Bregana; KL Klanjec; PL - Plavić; ZG - Zlatna Greda

laboratory measurements (Figure 2). However, the $95 \%$ confidence interval for Detector A measurements was on average $\pm 56 \%$ of the mean and for Detector $\mathrm{B} \pm 88 \%$ of the mean. This means that the $95 \%$ confidence intervals of in situ measurements overlapped with all laboratory ones but for a single result (the Detector B measurement in Batina)

Figure 3 shows the measurements results for ${ }^{214} \mathrm{~Pb}$ and ${ }^{214} \mathrm{Bi}$ together as the mother-daughter pair from the uranium decay chain. In laboratory measurements, their mean concentrations were almost identical and well within the $95 \%$ confidence interval. The only exception was the Zlatna Greda site, for which the laboratory measurements of ${ }^{214} \mathrm{Bi}$ were more than $10 \%$ higher than the concentration of ${ }^{214} \mathrm{~Pb}$.

All Detector A in situ ${ }^{214} \mathrm{~Pb}$ and ${ }^{214} \mathrm{Bi}$ measurements had overlapping $95 \%$ confidence intervals for the same location. On average, respective ${ }^{214} \mathrm{~Pb}$ and ${ }^{214} \mathrm{Bi}$ means measured with Detector A were $78 \%$ and $74 \%$ of the mean laboratory result.

Detector B measurements, in turn, the $95 \%$ confidence intervals $(2 \sigma)$ did not overlap for four of the seven sites, but $99 \%$ confidence intervals $(3 \sigma)$ did overlap for all sites. On average, ${ }^{214} \mathrm{~Pb}$ and ${ }^{214} \mathrm{Bi}$ means measured in situ were only $52 \%$ and $62 \%$ of the laboratory means, respectively. The average difference in mean in situ measurements between Detector A and Detector B was $23 \%$.
In contrast, both detectors yielded similar results of ${ }^{232} \mathrm{Th}$ in situ measurements (Figure 4), but these measurements undershot laboratory measurements. More specifically, $95 \%$ confidence intervals overlapped at all sites, but the average of in situ measurements was only $61 \%$ of the average laboratory measurements, ranging from $50 \%$ to $75 \%$.

As for ${ }^{137} \mathrm{Cs}$ in situ measurements (Figure 5), $95 \%(2 \sigma)$ confidence intervals overlapped at five of the seven sites, and $99 \%(3 \sigma)$ confidence intervals overlapped at all sites. Detector B yielded consistently higher measurements than Detector A. On average, Detector A means were $65 \%$ of the laboratory means, whereas Detector B means were very close to the laboratory ones (only $5 \%$ higher). However, these differences for individual sites ranged from $62 \%$ to $157 \%$ of laboratory measurements.

In situ measurements of ${ }^{40} \mathrm{~K}$ at all locations were lower than laboratory measurements (47\% on average) (Figure $6)$. These in situ results refer to uniform distribution. However, when we assumed the slab (step) distribution for InSiCal calculations, the values rose to $70 \%$ of the laboratory measurements (results in grey).

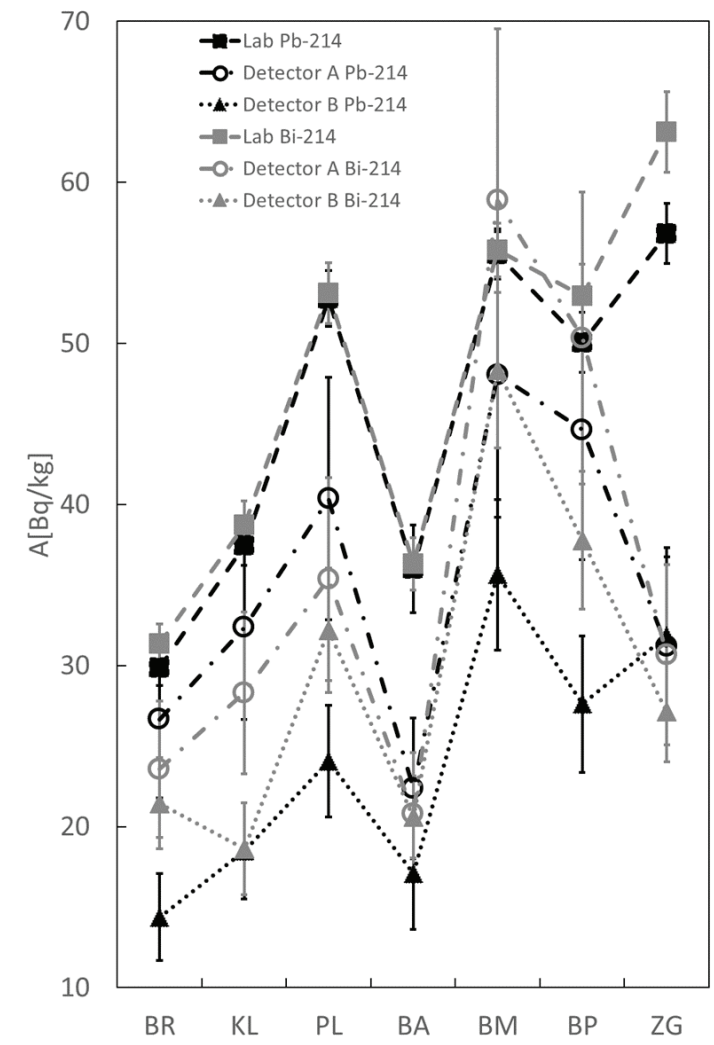

Figure 3 Results of ${ }^{214} \mathrm{~Pb}$ and ${ }^{214} \mathrm{Bi}$ measurements. BA - Batina; BM - Beli Manastir; BP - Baranjsko Petrovo Selo; BR - Bregana; KL - Klanjec; PL - Plavić; ZG - Zlatna Greda 


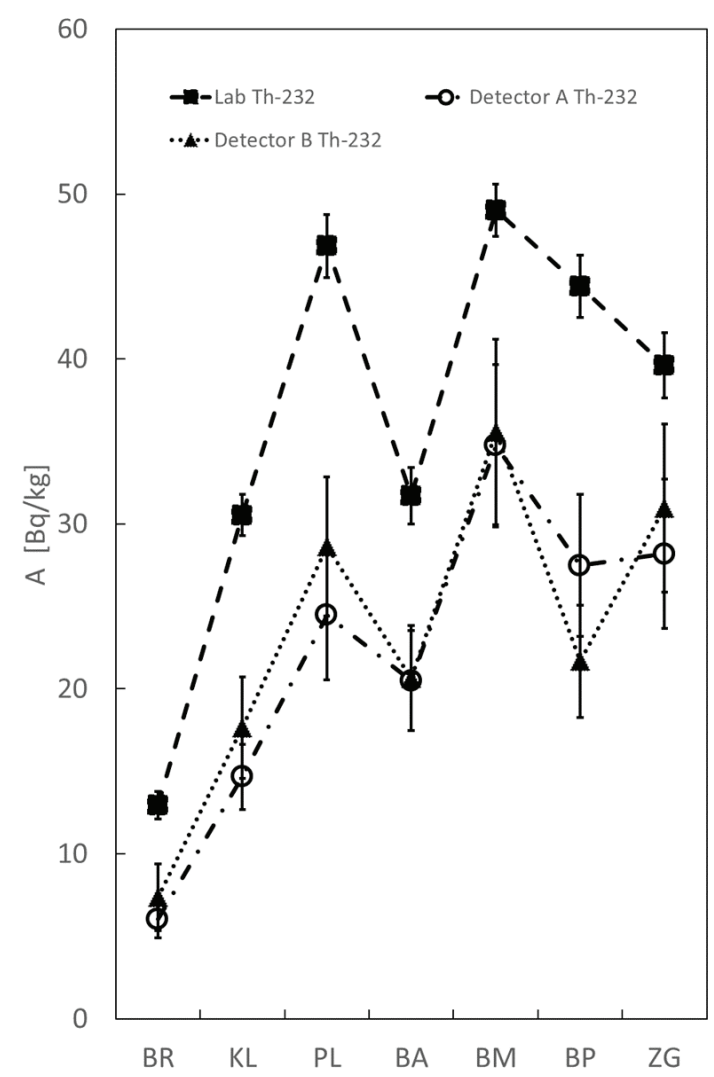

Figure 4 Results of ${ }^{232}$ Th measurements. BA - Batina; BM - Beli Manastir; BP - Baranjsko Petrovo Selo; BR - Bregana; KL Klanjec; PL - Plavić; ZG - Zlatna Greda

\section{DISCUSSION AND CONCLUSION}

Our findings suggest that in situ gamma spectrometry using InSiCal software can provide reasonably accurate data, but some improvements are needed.

One reason for the discrepancies between in situ and laboratory results may be that both sets of measurements measured slightly different things. In situ measurements measure a larger radiation field as is, which levels variations between soil samples measured in a laboratory. For laboratory measurements soil samples are rid of all grass, stones, and pieces that are difficult to grind. Laboratories seek to resolve this issue by combining multiple samples from a carefully selected grid to get a representative sample for the site. Still, removing pieces of stone and drying soil samples may result in higher laboratory measurements of ${ }^{40} \mathrm{~K}$ than in the field. Depending on the type of rock, stones may contain significantly less (or more, in case of granite) ${ }^{40} \mathrm{~K}$ than soil, and the water content in soil in the field, depending on the season, can result in 5-10\% lower in situ results measurements (13).

Another reason for discrepancies may lie in study design. We wanted to see if we could successfully finish the project within the eight working hours of simulated emergency. For that reason, we chose $17,000 \mathrm{~s}$ for peak response measurement (calibration) for both detectors, whereas in situ measurements lasted only 5,000 s each, as is expected in emergency situations. Taking into account the time needed for the team to travel to a macro-location (settlement and immediate surroundings), find an uncultivated clearing or a meadow, install the equipment, and complete the measurements, we could do only two locations a day. Depending on the situation and the needs, field teams could operate either in three eight-hour shifts a day, with equipment deployed in the field for 24 hours, or the way we did, which is more viable in cases of minor contamination of land of lesser importance, especially if conditions are such that it would not be safe to be in the field at night.

In situ gamma spectrometry could replace laboratory measurements when timing is critical. The InSiCal tool can easily convert raw measurements in counts per second to concentration per soil volume. The procedure was tested on two detectors of different efficiency, manufacturer, and cooling method and showed the good agreement in results between the two.

To further increase the viability of in situ measurements, additional research is needed. It should investigate whether different calibration and measurement times could yield different results. For typical soils in Croatia, in situ measurements should be compared with laboratory measurements in unprepared samples and samples prepared in a standard way to determine to which extent removal of

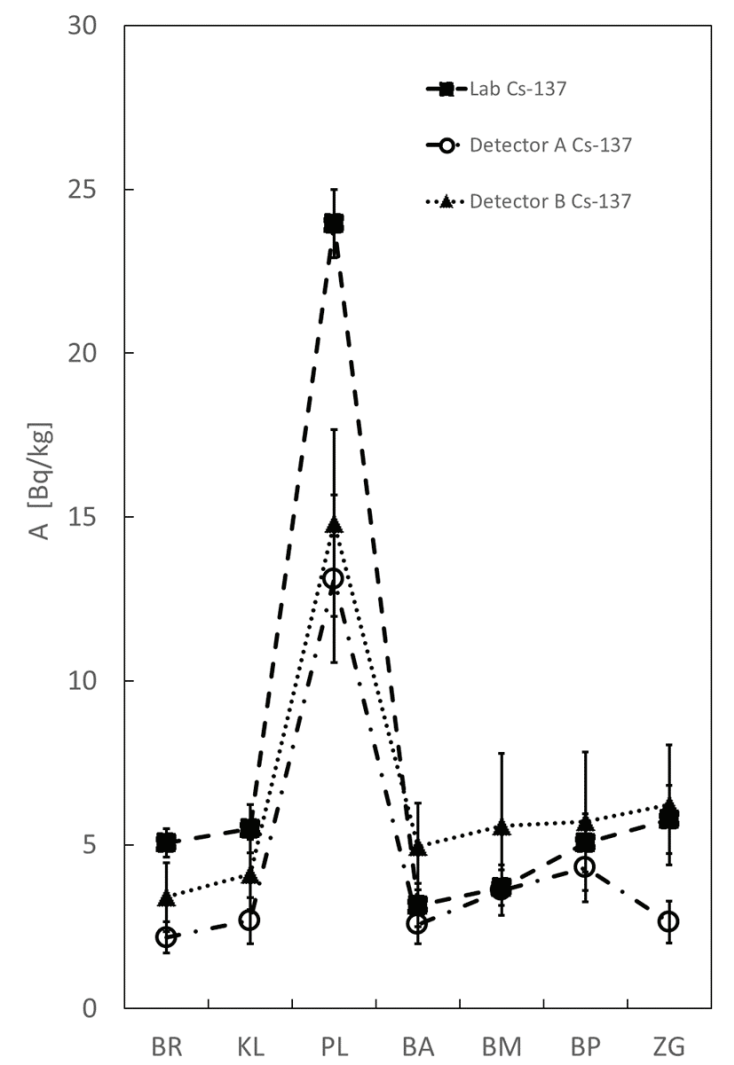

Figure 5 Results of ${ }^{137} \mathrm{Cs}$ measurements. BA - Batina; BM - Beli Manastir; BP - Baranjsko Petrovo Selo; BR - Bregana; KL Klanjec; PL - Plavić; ZG - Zlatna Greda 


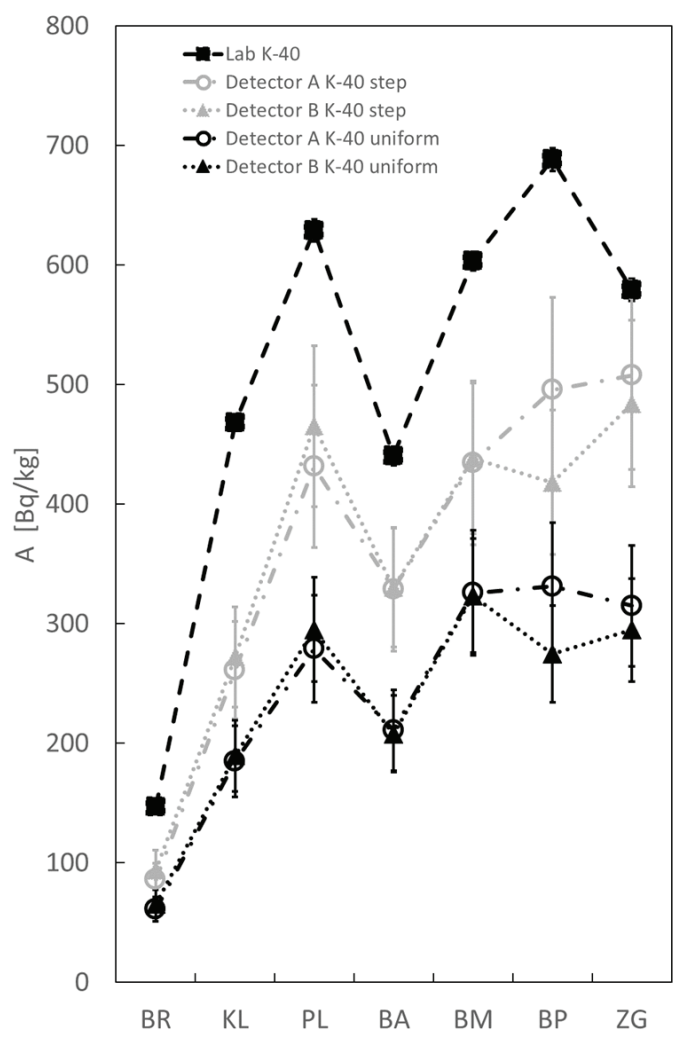

Figure 6 Results of ${ }^{40} \mathrm{~K}$ measurements. BA - Batina; BM - Beli Manastir; BP - Baranjsko Petrovo Selo; BR - Bregana; KL Klanjec; PL - Plavić; ZG - Zlatna Greda

grass, stone/gravel and water contributes to discrepancies. Furthermore, soil sampling should go at least one metre deep to test and verify the uniform or slab distribution selected in this study.

\section{REFERENCES}

1. Beck HL, Condo WJ, Lowder WM. Spectrometric Techniques for Measuring Environmental Gamma Radiation. HASL-150 [Technical Report] 1964 [displayed 23 February 2021]. Available at https://doi.org/10.2172/4611888

2. Beck HL. Environmental gamma radiation from deposited fission products, 1960-1964. Health Phys 1966;3:313-22. doi: 10.1097/00004032-196603000-00002

3. Beck HL, DeCampo J, Gogolak C. In Situ Ge(Li) and NaI(TL) gamma-Ray Spectrometry. HASL-258 1972 [displayed 23 February 2021]. Available at https://doi. org/10.2172/4599415

4. Miller KM, Shebell P. In situ gamma spectrometry: A tutorial for environmental radiation scientists. USDOE Report EML5571993 [displayed 23 February 2021]. Available at https:// doi.org/10.2172/10106357

5. Jacob P, Debertin K, Miller K, Roed J, Saito K, Sanderson D. Gamma-Ray Spectrometry in the Environment. ICRU Report 53, 1994 [displayed 23 February 2021]. Available at https://doi.org/10.1093/jicru/os27.2.Report53

6. International Atomic Energy Agency (IAEA). Characterization of radioactively contaminated sites for remediation purposes IAEA-TECDOC-1017;1998 [displayed 23 February 2021]
Available at https://www-pub.iaea.org/MTCD/Publications/ PDF/te_1017_prn.pdf

7. International Atomic Energy Agency (IAEA). Generic procedures for monitoring in a nuclear or radiological emergency. IAEA-TECDOC-1092;1999 [displayed 23 February 2021]. Available at https://www-pub.iaea.org/ MTCD/Publications/PDF/te 1092 web.pdf

8. ISO 18589-7:2013. Measurement of radioactivity in the environment - Soil - Part 7: In situ measurement of gammaemitting radionuclides [displayed 23 February 2021]. Available at https://www.iso.org/obp/ui/\#iso:std:iso:18589:7:ed-1:v1:en

9. Mauring A, Vidmar T, Gäfvert T, Drefvelin J, Fazio A. InSiCal - A tool for calculating calibration factors and activity concentrations in in situ gamma spectrometry. J Environ Radioact 2018;188:58-66. doi: 10.1016/j.jenvrad.2017.10.011

10. Nir-El Y, Haquin G. Minimum detectable activity in in situ $\gamma$-ray spectrometry. Appl Radiat Isot 2001;55:197-203. doi: 10.1016/s0969-8043(00)00377-8

11. Joint Committee for Guides in Metrology. Evaluation of Measurement Data - Guide to the Expression of Uncertainty in Measurement. JCGM 100;2008 [displayed 23 February 2021]. Available at https://www.bipm.org/utils/common/ documents/jcgm/JCGM 1002008 E.pdf

12. Helfer IK, Miller KM. Calibration factors for Ge detectors used for field spectrometry. Health Phys 1988;55:15-29. doi: 10.1097/00004032-198807000-00002

13. Herceg Romanić S, Kljaković-Gašpić Z, Bituh T, Žužul S, Dvoršćak M, Fingler S, Jurasović J, Klinčić D, Marović G, Orct T, Rinkovec J, Stipičević S. The impact of multiple anthropogenic contaminants on the terrestrial environment of the Plitvice Lakes National Park, Croatia. Environ Monit Assess 2016;188;27. doi: 10.1007/s10661-015-5030-4 


\section{Primjena nove in situ kalibracijske tehnike za gama-spektrometriju te usporedba in situ mjerenja i laboratorijskih} mjerenja

In situ gama-spektrometrija razvijena je u svrhu brzog mjerenja velikih površina tla nakon nuklearnih nesreća. Međutim, odgovarajuća kalibracija detektora za in situ mjerenja kompliciran je i dug proces. Računalni program InSiCal omogućuje njihovu brzu kalibraciju. Koristeći se InSiCal računalnim programom, dvama različitim kalibriranim HPGe detektorima usporedili smo kratka in situ mjerenja, kakva bi se očekivala u slučaju izvanrednoga događaja, s laboratorijskim mjerenjima uzoraka uzetih s istih lokacija. Naše je istraživanje pokazalo da in situ gama-spektrometrija uz primjenu InSiCal softvera daje relativno točne rezultate, ali su potrebna daljnja poboljšanja takve metode brzog mjerenja.

KLJUČNE RIJEČI: HPGe spektrometri; InSiCal softver; izvanredni događaji; mjerenje radionuklida; zračenje 